\title{
Autophagy Inhibitor 3-Methyladenine could not Modulate Rotenone Neurotoxicity in Primary Mesencephalic Cell Culture
}

\author{
El Inhibidor de la Autofagia 3-Metiladenina no logra Modular la Neurotoxicidad \\ de la Rotenona en el Cultivo Primario de Células Mesencefálicas
}

Khaled Radad ${ }^{1,2}$; Mubarak Al-Shraim ${ }^{1}$; Ahmed Al-Emam ${ }^{1,3}$; Wolf-Dieter Rausch ${ }^{4}$ \& Rudolf Moldzio ${ }^{4}$

RADAD, K.; AL-SHRAIM, M.; AL-EMAM, A.; RAUSCH, W. D. \& MOLDZIO, R. Autophagy inhibitor 3-methyladenine could not modulate rotenone neurotoxicity in primary mesencephalic cell culture. Int. J. Morphol., 38(3):530-535, 2020.

SUMMARY: Dysregulated autophagy, whether excessive or downregulated, has been thought to be associated with neurodegenerative disorders including Parkinson's disease. Accordingly, the present study was carried out to investigate whether 3-methyladenine, an autophagy inhibitor, can modulate the effects of rotenone on dopaminergic neurons in primary mesencephalic cell culture. Cultures were prepared from embryonic mouse mesencephala at gestation day 14. Four groups of cultures were treated on the 10th DIV for $48 \mathrm{~h}$ as follows: the first was kept as an untreated control, the second was treated with 3-methyladenine alone $(1,10,100,200 \mathrm{mM})$, the third was treated with $20 \mathrm{nM}$ rotenone and the fourth was co-treated with $20 \mathrm{nM}$ rotenone and 3-methyladenine $(1,10,100,200 \mathrm{mM})$. On the 12 th DIV, cultured cells were stained immunohistochemically against tyrosine hydroxylase and culture media were used to measure the levels of lactate dehydrogenase. 3methyladenine had no effects on both the survival of dopaminergic neurons and the release of lactate dehydrogenase. Rotenone significantly decreased the number of dopaminergic neurons and increased the levels of lactate dehydrogenase in the culture media. When cultures concomitantly treated with 3-methyladenine and rotenone, 3-methyladenine had no effect against rotenone-induced dopaminergic cell damage and lactate dehydrogenase release into the culture medium. In conclusion, the autophagy inhibitor 3-methyladenine could not modulate rotenone-induced dopaminergic cell damage in primary mesencephalic cell culture.

KEY WORDS: Autophagy; Dopaminergic neurons; Parkinson's disease; Rotenone; 3-methyladenine.

\section{INTRODUCTION}

Parkinson's disease (PD) is a common and progressive neurodegenerative disorder affecting about 10 million people worldwide (Ball et al., 2019). The prevalence of the disease is predicted to increase as the elderly people have significantly increased in the recent years (Heemels, 2016; Renaud \& Martinoli, 2019). The disease results primarily from the loss of dopamine-producing neurons (dopaminergic) in the substantia nigra pars compacta (SNpc) (Khalifeh et al., 2019; Yao et al., 2019) and subsequent deficiency of striatal dopamine (Poewe et al., 2017). Parkinson's disease as a motor disorder is characterized by a number of classic motor signs including rest tremors, bradykinesia, rigidity and stooping posture (Beitz, 2014). Non-motor symptoms such as sleep disorders, cognitive/ neurobehavioral abnormalities, autonomic dysfunction, and sensory abnormalities such as anosmia, paraesthesia and pain are considered (Jankovic, 2008).
However the exact etiology of PD is still unclear, two forms of the disease exist; familial and sporadic. Familial form accounts for $~ 10-15 \%$ of all PD cases and is associated with seven causal genes including alpha-synuclein (SNCA), leucine-rich repeat Kinase 2 (LRRK2), glucocerebrosidase (GBA), vacuolar protein sortingassociated protein 35 (VPS35), parkin RBR E3 ubiquitin protein ligase (PARK2),phosphatase and tensing homologinduced Kinase 1 (PINK1), and Parkinson protein 7 (PARK7) (Verstraeten et al., 2015; Kalinderi et al., 2016). Sporadic PD affects $\sim 85-90 \%$ of the cases and is believed to return to environmental exposures, most notably, chemicals, pesticides and heavy metals (Castillo et al., 2017; Pouchieu et al., 2018).

Autophagy is a crucial catabolic process that keeps homeostasis inside cells and helps them to face stressors

\footnotetext{
${ }^{1}$ Department of Pathology, College of Medicine, King Khalid University, Abha, Saudi Arabia.

${ }^{2}$ Department of Pathology, Faculty of Veterinary Medicine, Assiut University, Assiut, Egypt.

${ }^{3}$ Forensic and Toxicology Department, Faculty of Medicine, Mansoura University, Mansoura, Egypt.

${ }^{4}$ Institute of Medical Biochemistry, Department for Biomedical Sciences, University of Veterinary Medicine Vienna, Austria.
} 
through delivering misfolded proteins and damaged organelles to lysosomes for degradation (Cerri \& Blandini, 2018; Kirkin, 2019). Recently, increasing evidence from PD patients and PD experimental models has showed that autophagy plays an essential role in PD pathogenesis (Zhang et al., 2012). In this context, Dehay et al. (2010) found that post-mortem PD brain samples have an increased number of undegraded autophagosomes and a lower number of autophagolysosomes. Park et al. (2014) observed that treatment of mice with MPP+ inhibited formation of autophagosome and increased expression of a-synuclein. Parganlija et al. (2014) showed that knock downing of PINK1 in SH-SY5Y cells resulted in downregulation of key autophagic genes such as Beclin, LC3 and LAMP-2.

Accordingly, the current study was designed to investigate the role of the autophagy-inhibitor 3methyladenine against rotenone-induced dopaminergic cell death in the primary mesencephalic cell culture.

\section{MATERIAL AND METHOD}

Preparation of primary mesencephalic cell culture. Pregnant OF1/SPF mice were cared and handled in accordance with the guidelines of the European Union Council (86/609/EU) for the use of laboratory animals. Cultures were prepared from OF1/SPF embryos on the 14th day of gestation according to Radad et al. (2018). Briefly, brains were released from skulls, and mesencephala were dissected and cut into small pieces in a drop of D-PBS (Invitrogen, Germany). The tissues were transferred into a Griener centrifuge tube containing $2 \mathrm{ml}$ of $0.2 \%$ trypsin solution (Invitrogen, Germany) and $2 \mathrm{ml}$ of $0.02 \%$ DNase I solution (Roche, Germany). After incubation in water bath at $37^{\circ} \mathrm{C}$ for $7 \mathrm{~min}, 2 \mathrm{ml}$ of trypsin inhibitor $(0.125 \mathrm{mg} /$ ml) (Invitrogen, Germany) were added, the tissue was centrifuged at 100x $\mathrm{g}$ for 4 min and the supernatant was aspired. The tissue pellet was then mechanically triturated with a fire-polished Pasteur pipette. Dissociated cells were seeded at a density of 257.000 cells $/ \mathrm{cm}^{2}$ in DMEM (Sigma, Germany) supplemented with $4 \mathrm{mM}$ glutamine, $10 \mathrm{mM}$ HEPES buffer, $30 \mathrm{mM}$ glucose, $100 \mathrm{IU} / \mathrm{ml}$ penicillin, 0.1 $\mathrm{mg} / \mathrm{ml}$ streptomycin and $10 \%$ heat-inactivated fetal calf serum (Sigma, Germany). The medium was exchanged with the same medium on the 1st day in vitro (DIV) and on the $3^{\text {rd }}$ DIV. On the $5^{\text {th }}$ DIV, half of the medium was replaced by serum-free DMEM containing $0.02 \mathrm{ml}$ of B27/ml (Invitrogen, Germany). Serum-free supplemented DMEM was used from the 6th DIV and subsequently replaced every 2nd day.
Treatment of cultures with 3-MA. A stock solution of $10 \mathrm{mM}$ was prepared by dissolving $1.49 \mathrm{mg}$ of 3-MA (Sigma-Aldrich, Germany) in $1 \mathrm{ml}$ distilled water. Final concentrations were prepared in DMEM. On the 10th DIV, cultures were treated with 3-MA alone (1, 10, 100, $200 \mathrm{mM})$ for $48 \mathrm{~h}$ to investigate its effect on the survival of dopaminergic neurons and the release of lactate dehydrogenase (LDH) in the culture media.

Treatment of cultures with rotenone. A rotenone (SigmaAldrich, Germany) stock solution $(10 \mathrm{mM})$ was prepared by dissolving $3.94 \mathrm{mg}$ of rotenone in $1 \mathrm{ml}$ DMSO. Final concentrations of rotenone were prepared in DMEM. Fresh rotenone solutions were used in each treatment to avoid its breakdown by storage. On the 10th DIV, cultures were treated with $20 \mathrm{nM}$ of rotenone for $48 \mathrm{~h}$.

Treatment of cultures with rotenone and 3-MA. Cultures were concomitantly treated with rotenone $(20 \mathrm{nM})$ and 3MA $(1,10,100,200 \mathrm{mM})$ on the 10th DIV for $48 \mathrm{~h}$ to investigate the effect of autophagy inhibitor 3-MA against rotenone-induced dopaminergic cell damage.

Identification of dopaminergic neurons. Dopaminergic neurons were identified by tyrosine hydroxylase immunostaining. On the $12^{\text {th }}$ DIV, cultured cells were rinsed carefully with phosphate buffered saline (PBS, pH 7.2) and fixed with histochoice for $15 \mathrm{~min}$ at room temperature. After permeabilization with $0.4 \%$ Triton $\mathrm{X}-100$ for $30 \mathrm{~min}$ at room temperature, non-specific binding sites were blocked with 5 $\%$ horse serum (Vectastain ABC Elite kite) for $90 \mathrm{~min}$ at room temperature. Then, cells were incubated with anti-TH primary antibody over night at $4{ }^{\circ} \mathrm{C}$ and biotinylated secondary antibody (Vectastain) and avidin-biotinhorseradish peroxidase complex (Vectastain) for $90 \mathrm{~min}$ at room temperature. The reaction product was developed in a solution of diaminobenzidine $(1.4 \mathrm{mM})$ in PBS containing $3.3 \mathrm{mM}$ hydrogen peroxide $\left(\mathrm{H}_{2} \mathrm{O}_{2}\right)$. Dopaminergic neurons were counted with a Nikon inverted microscope in 10 randomly selected fields/well at magnification10’.

Measurement of LDH activity. Measuring LDH activity in the culture media is usually used to quantify cell damage. At the end of each treatment, culture media were collected and used to measure LDH activity with a cytotoxic detection kit according to the manufacturer's instructions. In brief, $\mathrm{NADH}+\mathrm{H}+$ produced from NAD + by LDH is transferred by diaphorase to the yellow tetrazolium salt 2-[4iodophenyl]-3-[4-nitrophenyl]-5-phenyltetrazolium chloride (INT) resulting in red formazan formation. The latter was measured spectrophotometrically at $490 \mathrm{~nm}$ with a reference at $688 \mathrm{~nm}$. Supplemented medium was used as a blank and subtracted as background. 
Statistics. Data were obtained from three experimental repeats (4 wells/experiment) for each treatment condition and presented as mean \pm standard error of mean (SEM). Comparisons between groups were made using ANOVA and post-hoc Duncan's test using IBM SPSS statistics 22. ( $p<0.05$ was considered as statistically significant).

\section{RESULTS}

Effect of 3-MA on primary mesencephalic cell culture. Treatment of primary mesencephalic cell cultures with different concentrations of 3-MA $(1,10,100,200 \mathrm{mM})$ on the 10th DIV for $48 \mathrm{~h}$ did not affect the survival of dopaminergic neurons (Fig. 1A). 3-MA also had no effect on the morphology of dopaminergic neurons. Dopaminergic neurons in both untreated controls and 3-MA-treated cultures were many with long and branched neuritis (Fig. 1B). Moreover, 3-MA did not affect the release of LDH into the culture medium compared to untreated controls (Fig. 2).

Effect of concomitant treatment with 3-MA and rotenone on primary mesencephalic cell cultures. Administration of rotenone $(20 \mathrm{nM})$ to primary mesencephalic cell cultures

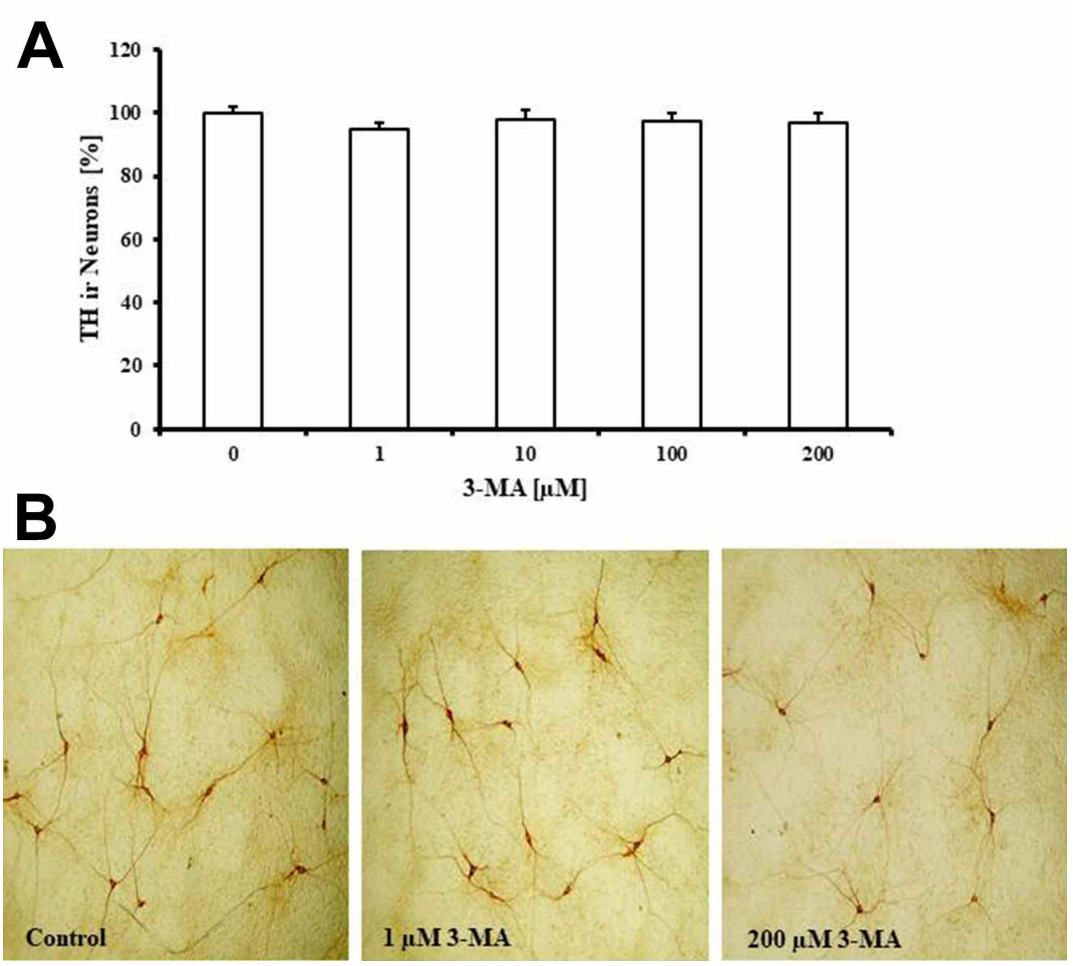

Fig. 1. Treatment of cultures with different concentrations of 3-MA $(1,10,100,200$ $\mathrm{mM}$ ) on the 10th DIV for $48 \mathrm{~h}$. $100 \%$ corresponds to the total number of dopaminergic neurons (the average is 27.43 cells/field) after 12 DIV in untreated control cultures. Values represent the mean \pm SEM of three independent experiments with four wells in each treatment $(\mathrm{p}=0.223)$.

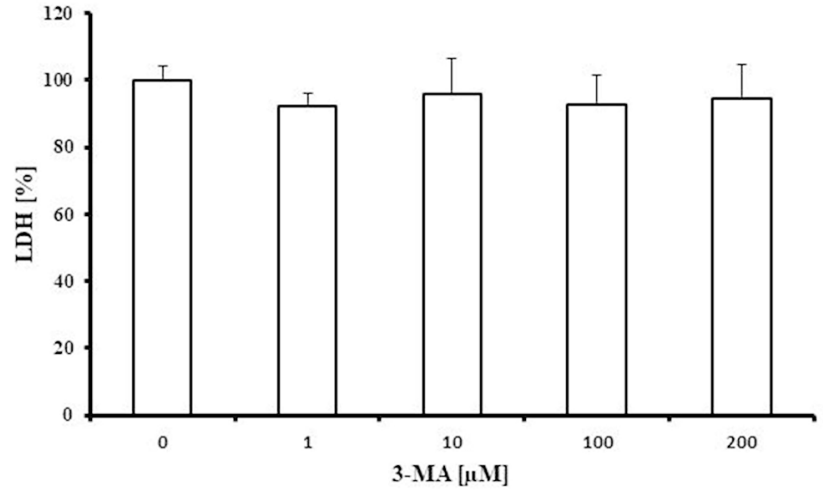

Fig. 2. Measurement of LDH in the culture medium following treatment of cultures with different concentrations of 3-MA $(1,10$, $100,200 \mathrm{mM}$ ) on the 10th DIV for $48 \mathrm{~h} .100 \%$ corresponds to the amount of LDH in the culture medium on the 12th DIV. Values represent the mean \pm SEM of three independent experiments with four wells in each treatment $(\mathrm{p}=0.548)$.

on the 10th DIV for $48 \mathrm{~h}$ significantly decreased the number of dopaminergic neurons by about $25 \%$ compared to untreated controls (Fig. 3A). When cultures were concomitantly treated with 3-MA and rotenone on the 10th DIV for $48 \mathrm{~h}, 3$-MA did not modulate rotenone's effects on dopaminergic neurons compared to rotenone-treated cultures (Fig. 3A). Treatment of cultures with rotenone markedly injured dopaminergic neurons. Survived neurons appeared few with shortened and thickened neuritis (Fig. 3B). 3-MA also did not affect the morphology of survived dopaminergic neurons in rotenone-treated cultures (Fig. 3B). Also, rotenone was found to increase the release of LDH into the culture medium compared to untreated control cultures and 3-MA had no significant effect on LDH levels compared to rotenone-treated cultures (Fig. 4). 
A
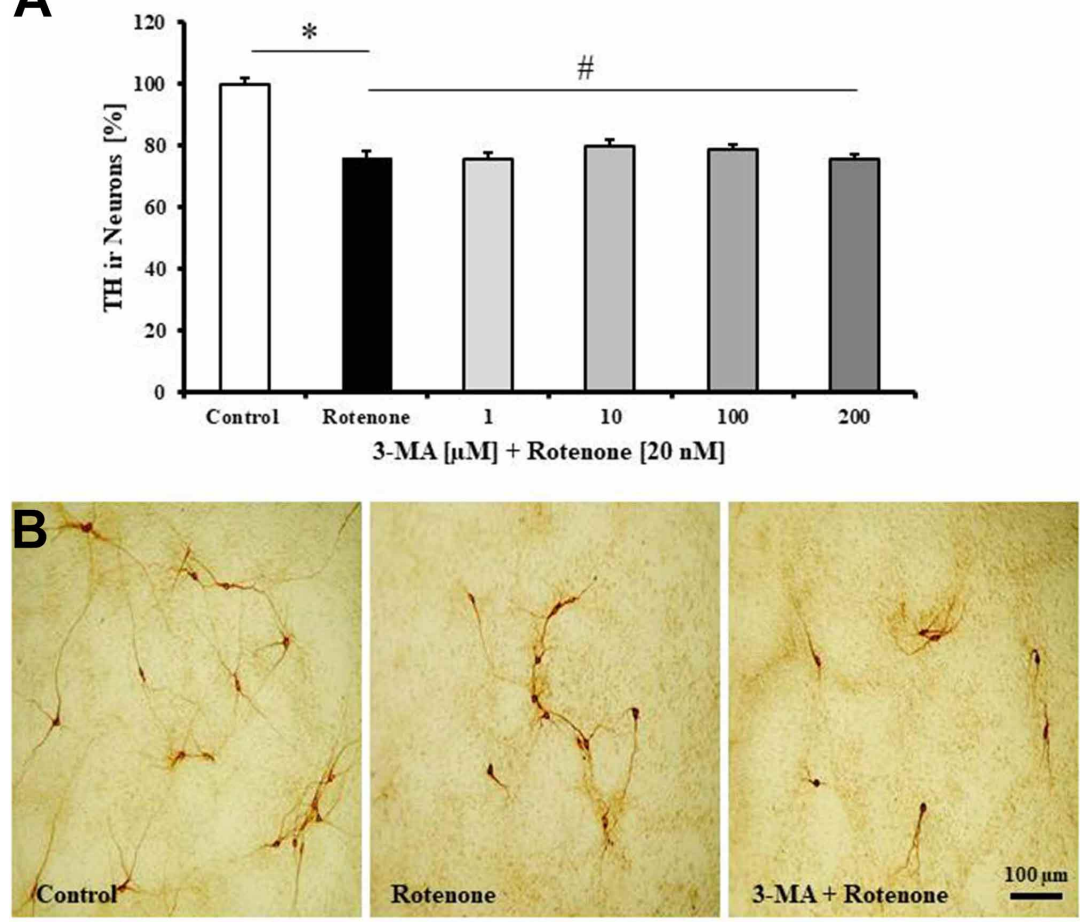

Fig. 3. Effect of concomitant treatment of cultures with 3-MA $(1,10,100,200 \mathrm{mM})$ and rotenone $(20 \mathrm{nM})$ on the 10 th DIV for $48 \mathrm{~h}$. A) Number of dopaminergic neurons. $100 \%$ corresponds to the total number of dopaminergic neurons (the average is 29.67 cells/field) after 12 DIV in untreated control cultures. Values represent the mean \pm SEM of three independent experiments with four wells in each treatment. $\left({ }^{*} \mathrm{p}<0.001, \# \mathrm{p}<0.184\right)$. B) Representative micrographs of dopaminergic neurons after 12 DIV. Untreated control culture shows many dopaminergic neurons with long and branched processes. Rotenonetreated culture shows lower number of dopaminergic neurons with few, shortened and thickened neurites. Concomitant treatment of cultures with rotenone and 3-MA did not alter the morphology of surviving dopaminergic neurons compared to rotenone-treated cultures.

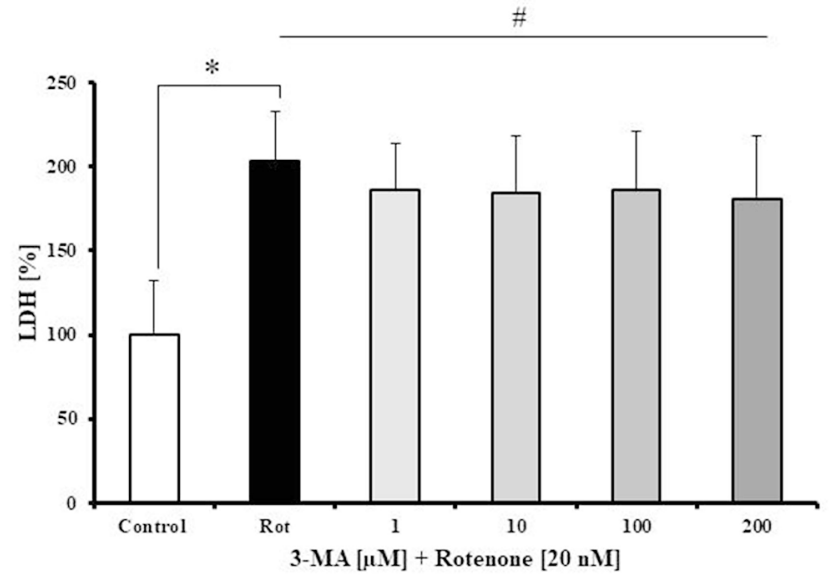

Fig. 4. Measurement of LDH in the culture medium following concomitant treatment of cultures with different concentrations of 3-MA $(1,10,100,200 \mathrm{mM})$ and rotenone $(20 \mathrm{nM})$ on the 10th DIV for 48 h. $100 \%$ corresponds to the amount of LDH in the culture medium on the 12 th DIV. Values represent the mean \pm SEM of three independent experiments with four wells in each treatment $(* \mathrm{p}<0.001, \# \mathrm{p}=0.064)$.

\section{DISCUSSION}

Dysregulated autophagy has been observed in the brains of PD patients, and animal and cellular models of PD indicating the distinct role of autophagy in the pathogenesis of the disease (Lynch-Day et al., 2012; Janda et al., 2012).
Accordingly, the present study aimed to investigate whether inhibition of the autophagy process would modulate rotenone-induced dopaminergic cell damage in primary mesencephalic cell culture. We have previously showed that activation of autophagy by rapamycin protected dopaminergic neurons against rotenone-induced damage in primary mesencephalic cell culture.

Treatment of cultures with different concentrations of 3-MA $(1,10,100,200 \mathrm{mM})$ was shown to have no effect on both the survival of dopaminergic neurons and the release of LDH into the culture medium. This might occur because autophagic process is minimal and its inhibition was not effective in this well-enriched and short-lived cell culture type. In parallel, fluorescence staining of untreated primary mesencephalic cell culture with LysotrackerÒ deep red, a dye that retained in acidic subcellular organelles such as phagolysosomes, showed very low red fluorescence intensity (Radad et al., 2015).

Administration of $20 \mathrm{nM}$ rotenone to the cultures significantly decreased the number of dopaminergic neurons and increased the release of LDH into the culture medium compared to untreated control cultures. Similarly, rotenone's neurotoxicity was shown in different in vitro and in vivo models since 2000 when Betarbet and her colleagues described rotenone as a PD neurotoxin (Betarbet et al., 2000). For example, Radad et al. (2015) showed that $20 \mathrm{nM}$ 
rotenone significantly destroyed dopaminergic neurons and increased LDH release in the culture medium. Im et al. (2013), found that rotenone decreased the viability of PC12 cells. Tapias et al. (2014), observed that rotenone led to loss of dopaminergic neurons and nigrostriatal terminals in rats. This damaging effect of rotenone on cultured cells was associated with increased autophagic process as indicated by the intense red fluorescence of the LysotrackerÒ deep red compared to untreated control cultures (see Radad et al., 2015). Interestingly, concomitant treatment of cultures with rotenone and 3-MA did not modulate rotenone's effects on both the survival of dopaminergic neurons and the release of $\mathrm{LDH}$ into the culture medium. However, inhibition of autophagy was reported to deleteriously affect aged and toxin-sensitized and tumor cells. For instance, Stroikin et al. (2004) found that treatment of growtharrested human fibroblasts, a classical model of cellular aging, with 3-MA resulted in moderate increase in mitochondria with lowered membrane potential. Pickard et al. (2015) showed that 3-MA increased autophagic vesicle formation and apoptotic cell death of LNCaP prostate cancer cells. This toxic effect of 3-MA was reported to be due to blocking of autophagosome formation via the inhibition of class III PI3K with subsequent accumulation of misfolded proteins and altered cell organelles leading to cell damage (Wu et al., 2010).

In conclusion, 3-MA, an autophagy inhibitor, does not modulate rotenone-induced dopaminergic cell damage in primary mesencephalic cell culture.

\section{ACKNOWLEDGEMENTS}

The authors extend their appreciation to the Deanship of Scientific Research at King Khalid University for funding this work through research groups program under grant number R.G.P. 1/125/40.

RADAD, K.; AL-SHRAIM, M.; AL-EMAM, A.; RAUSCH, W. D. \& MOLDZIO, R. El inhibidor de la autofagia 3-metiladenina no logró modular la neurotoxicidad de la rotenona en el cultivo primario de células mesencefálicas. Int. J. Morphol., 38(3):530535,2020 .

RESUMEN: Se estima que la autofagia desregulada, ya sea excesiva o con baja regulación, está asociada con trastornos neurodegenerativos, incluyendo la enfermedad de Parkinson. En consecuencia, el se realizó este estudio para investigar si la 3metiladenina, un inhibidor de la autofagia,puede modular los efectos de la rotenona en las neuronas dopaminérgicas en el cultivo primario de células mesencefálicas. Los cultivos se prepararon a partir de mesencéfalo de ratón embrionario el día 14 de gestación. Cuatro grupos de cultivos se trataron en el $10^{\circ}$ DIV durante $48 \mathrm{~h}$ de la siguiente manera: el primer grupo se mantuvo como un control no tratado, el segundo se trató con 3-metiladenina sola (1, 10, 100, $200 \mathrm{mM}$ ), el tercer grupo se trató con rotenona $20 \mathrm{nM}$ y el cuarto se trató conjuntamente con rotenona $20 \mathrm{nM}$ y 3 -metiladenina (1, 10, 100, $200 \mathrm{mM})$. En el 12 ${ }^{\circ} \mathrm{DIV}$; las células cultivadas fueron tratadas mediante tinción inmunohistoquímica en tirosina hidroxilasa y se usaron medios de cultivo para medir los niveles de lactato deshidrogenasa. La 3-metiladenina no tuvo efectos tanto en la supervivencia de las neuronas dopaminérgicas como en la liberación de lactato deshidrogenasa. La rotenona disminuyó significativamente el número de neuronas dopaminérgicas y se observó un aumento de los niveles de lactato deshidrogenasa en los medios de cultivo. Cuando los cultivos tratados concomitantemente con 3-metiladenina y rotenona, la 3metiladenina no tuvo efecto contra el daño celular dopaminérgico inducido por la rotenona y la liberación de lactato deshidrogenasa en el medio de cultivo. En conclusión, el inhibidor de la autofagia 3-metiladenina no moduló el daño celular dopaminérgico inducido por la rotenona en el cultivo celular mesencefálico primario.

PALABRAS CLAVE: Autofagia; Neuronas dopaminérgicas; Enfermedad de Parkinson; Rotenona; 3 metiladenina.

\section{REFERENCES}

Ball, N.; Teo, W. P.; Chandra, S. \& Chapman, J. Parkinson's disease and the environment. Front. Neurol., 19:218, 2019.

Beitz, J. M. Parkinson's disease: a review. Front. Biosci. (Schol. Ed.), 6:6574, 2014.

Betarbet, R.; Sherer, T. B.; MacKenzie, G.; Garcia-Osuna, M.; Panov, A. V. \& Greenamyre, J. T. Chronic systemic pesticide exposure reproduces features of Parkinson's disease. Nat. Neurosci., 3(12):1301-6, 2000.

Castillo, S.; Muñoz, P.; Behrens, M. I.; Diaz-Grez, F. \& Segura-Aguilar, J. On the role of mining exposure in epigenetic effects in Parkinson's disease. Neurotox. Res., 32(2):172-4, 2017

Cerri, S. \& Blandini, F. Role of autophagy in Parkinson's disease. Curr. Med. Chem., 26(20):3702-18, 2019.

Dehay, B.; Bové, J.; Rodríguez-Muela, N.; Perier, C.; Recasens, A.; Boya, P. \& Vila, M. Pathogenic lysosomal depletion in Parkinson's disease. J. Neurosci., 30(37):12535-44, 2010

Heemels, M. T. Neurodegenerative diseases. Nature, 539(7628):179, 2016.

Im, A. R.; Kim, Y. H.; Uddin, M. R.; Chae, S.; Lee, H. W.; Kim, Y. S. \& Lee, M. Y. Neuroprotective effects of Lycium chinense Miller against rotenone-induced neurotoxicity in PC12 Cells. Am. J. Chin. Med., 41(6):1343-59, 2013.

Janda, E.; Isidoro, C.; Carresi, C. \& Mollace, V. Defective autophagy in Parkinson's disease: role of oxidative stress. Mol. Neurobiol., 46(3):63961, 2012.

Jankovic, J. Parkinson's disease: clinical features and diagnosis. J. Neurol. Neurosurg. Psychiatry, 79(4):368-76, 2008.

Kalinderi, K.; Bostantjopoulou, S. \& Fidani, L. The genetic background of Parkinson's disease: current progress and future prospects. Acta Neurol. Scand., 134(5):314-26, 2016.

Khalifeh, M.; Barreto, G. E. \& Sahebkar, A. Trehalose as a promising therapeutic candidate for the treatment of Parkinson's disease. Br. J. Pharmacol., 176(9):1173-89, 2019. 
Kirkin, V. History of the selective autophagy research: how did it begin and where does it stand today? J. Mol. Biol., 2019. doi: 10.1016/ j.jmb.2019.05.010 [Online ahead of print].

Lynch-Day, M. A.; Mao, K.; Wang, K.; Zhao, M. \& Klionsky, D. J. The role of autophagy in Parkinson's disease. Cold Spring Harb. Perspect. Med., 2(4):a009357, 2012.

Parganlija, D.; Klinkenberg, M.; Domínguez-Bautista, J.; Hetzel, M.; Gispert, S.; Chimi, M. A.; Dröse, S.; Mai, S.; Brandt, U.; Auburger, G.; et al. Loss of PINK1 impairs stress-induced autophagy and cell survival. PLoS One, 9(4):e95288, 2014.

Park, H. J.; Shin, J. Y.; Kim, H. N.; Oh, S. H. \& Lee, P. H. Neuroprotective effects of mesenchymal stem cells through autophagy modulation in a parkinsonian model. Neurobiol. Aging, 35(8):1920-8, 2014.

Pickard, R. D.; Spencer, B. H.; McFarland, A. J.; Bernaitis, N.; Davey, A. K.; Perkins, A. V.; Chess-Williams, R.; McDermott, C. M.; Forbes, A.; Christie, D.; et al. Paradoxical effects of the autophagy inhibitor 3methyladenine on docetaxel-induced toxicity in PC-3 and LNCaP prostate cancer cells. Naunyn Schmiedebergs Arch. Pharmacol., 388(7):793-9, 2015.

Poewe, W.; Seppi, K.; Tanner, C. M.; Halliday, G. M.; Brundin, P.; Volkmann, J.; Schrag, A. E. \& Lang, A. E. Parkinson disease. Nat. Rev. Dis. Primers, 23:17013, 2017.

Pouchieu, C.; Piel, C.; Carles, C.; Gruber, A.; Helmer, C.; Tual, S.; Marcotullio, E.; Lebailly, P. \& Baldi, I. Pesticide use in agriculture and Parkinson's disease in the AGRICAN cohort study. Int. J. Epidemiol., 47(1):299-310, 2018.

Radad, K.; Moldzio, R. \& Rausch, W.D. Rapamycin protects dopaminergic neurons against rotenone-induced cell death in primary mesencephalic cell culture. Folia Neuropathol., 53(3):250-61, 2015.

Radad, K.; Moldzio, R.; Al-Shraim, M.; Al-Emam, A. \& Rausch, W. D. Long-term neurotoxic effects of domoic acid on primary dopaminergic neurons. Toxicol. In Vitro, 52:279-85, 2018.

Renaud, J. \& Martinoli, M.G. Considerations for the use of polyphenols as therapies in neurodegenerative diseases. Int. J. Mol. Sci., 20(8), 2019. doi: 10.3390/ijms20081883

Stroikin, Y., Dalen, H.; Lööf, S. \& Terman, A. Inhibition of autophagy with 3-methyladenine results in impaired turnover of lysosomes and accumulation of lipofuscin-like material. Eur. J. Cell Biol., 83(10):58390, 2004.

Tapias, V.; Cannon, J. R. \& Greenamyre, J. T. Pomegranate juice exacerbates oxidative stress and nigrostriatal degeneration in Parkinson's disease. Neurobiol. Aging, 35(5):1162-76, 2014.

Verstraeten, A.; Theuns, J. \& Van Broeckhoven, C. Progress in unraveling the genetic etiology of Parkinson disease in a genomic era. Trends Genet., 31(3):140-9, 2015.

Wu, Y. T.; Tan, H. L.; Shui, G.; Bauvy, C.; Huang, Q.; Wenk, M. R.; Ong, C. N.; Codogno, P. \& Shen, H. M. Dual role of 3-methyladenine in modulation of autophagy via different temporal patterns of inhibition on class I and III phosphoinositide 3-kinase. J. Biol. Chem., 285:1085061,2010

Yao, M. L.; Zhang, H.; Xu, Y.; Zhang, S. M.; Gao, Y. Z.; Shu, M. \& Zhang, J. J. Neuropsychiatric symptoms and cognitive impairment in Chinese patients with Parkinson's disease in Han and Hui Ethnicity. Curr. Med. Sci., 39(1)122-6, 2019.

Zhang, L.; Dong, Y.; Xu, X. \& Xu, Z. The role of autophagy in Parkinson's disease. Neural Regen. Res., 7(2):141-5, 2012.

\author{
Corresponding author: \\ Prof. Dr. Khaled Radad, Ph.D. \\ Department of Pathology \\ College of Medicine \\ King Khalid University \\ Abha \\ SAUDI ARABIA
}

Email: khaledradad@hotmail.com

Received: 26-09-2019

Accepted: 26-10-2019 